Louisiana State University

LSU Digital Commons

4-2001

Of Manatees, Mangroves, and the Mississippi River: Is There an Estuarine Signature for the Gulf of Mexico?

R. Eugene Turner

Follow this and additional works at: https://digitalcommons.Isu.edu/oceanography_coastal_pubs

Digitart of the Oceanography Commons

Commons

Network

Logo 


\title{
Of Manatees, Mangroves, and the Mississippi River: Is There an Estuarine Signature for the Gulf of Mexico?
}

\author{
R. Eugene TurneR* \\ Coastal Ecology Institute and Department of Oceanography and Coastal Sciences, Louisiana State \\ University, Baton Rouge, Louisiana 70803
}

\begin{abstract}
Important parameters of estuarine variability include morphology, flushing times, nutrient loading rates, and wetland: water ratios. This variability both reflects and disguises underlying relationships between the physics and biology of estuaries, which this comparative analysis seeks to reveal, using the Gulf of Mexico (GOM) estuaries as a starting point. A question used to focus this analysis is: are the GOM estuaries unique? The GOM receives the Mississippi River, a uniquely large, world-class river, which dominates the freshwater and nutrient inflows to the GOM continental shelf, whose margins include 35 major estuarine systems. These GOM estuaries have $28 \%$ and $41 \%$ of the U.S. estuarine wetlands and open water, respectively. Within the GOM, estuarine nitrogen, phosphorus, and suspended matter loading varies over 2 orders of magnitude. Anoxic estuarine events tend to occur in estuaries with relatively slow freshwater turnover and high nitrogen loading. Compared to estuaries from other regions in the U.S., the average GOM estuary is distinguished by shallower depths, faster freshwater flushing time, a higher wetland area:open water area ratio, greater fisheries yield per area wetland, lower tidal range, and higher sediment accumulation rates. The average GOM estuary often, but not always, has a flora and fauna not usually found in most other U.S. estuaries (e.g., manatees and mangroves). Coastal wetland loss in the GOM is extraordinarily high compared to other regions and is causally linked to cultural influences. Variations in nutrient loading and population density are very large among and within estuarine regions. This variation is large enough to demonstrate that there are insufficient systematic differences among these estuarine regions that precludes cross-system analyses. There are no abrupt discontinuities among regions in the fisheries yields per wetland area, tidal amplitude and vegetation range, salt marsh vertical accretion rates and organic accumulations, nitrogen retention, or wetland restoration rates. These results suggest that a comparative analysis emphasizing forcing functions, rather than geographic uniqueness, will lead to significant progress in understanding how all estuaries function, are perturbed, and even how they can be restored.
\end{abstract}

\section{Introduction}

Individual estuaries are certainly interesting subjects for appreciation and study, even though the apparent uniqueness of a single estuary may sometimes thwart the appropriation of knowledge and experience gained from one estuary from being applied to all estuaries. These information transfers are hindered by an undeniable lack of comparable data and institutional barriers, but also because estuaries can be exquisitely interesting when considered individually. The shapes, geological context, urban densities, soil types, etc., of estuaries are wonderfully diverse. We can maintain appreciation for this variability while also analyzing it to illuminate how estuaries work, to discover how they are constrained, and, perhaps, to assist in their conservation. This is a potentially useful effort as the quantity and quality of stressors ascend unabated this century, and because there are very, very few examples of system-wide estuarine restoration. Scientists can contribute to these efforts by

\footnotetext{
* Tele: 225/578-6454; fax: 225/578-6326; e-mail: euturne@1su.edu.
}

offering and testing perspectives in a quantitative way. Sometimes we can do this quite well with simple comparisons among estuarine systems as Nixon and Howarth, among others, have shown with considerable success (e.g., Nixon 1979, 1992; Howarth et al. 1996; Nixon et al. 1996). I will attempt here to compare various aspects of Gulf of Mexico (GOM) estuaries and other U.S. estuaries. Although most of the geomorphic variability, water quality changes, and habitat losses of other regions are found in GOM estuaries (and to varying degrees), this analysis will not be a complete analysis because sufficiently large and complete data sets are not yet available.

The impetus for this effort was the request from the Estuarine Research Federation for a series of talks on the nation's estuaries that were subsequently given at the 1997 Biennial meeting. These talks were designated as Estuarine Signatures and sub-divided by regional groupings. I wondered then, and do now, about the degree to which GOM estuaries are readily distinguishable from all other U.S. estuaries. The question with which I began preparing this analysis was: are the GOM estuaries unique? The discussion starts with a comparison of 
physical, biological, and land-use data for the GOM estuaries and, where possible, other regional estuaries. It ends with a partial response to the question posed in the beginning.

\section{Data Sources}

The National Oceanic and Atmospheric Administration (NOAA) compiles various statistics on the size, land cover, and hydrology of U.S. estuaries (Strategic Assessment Branch 1985, 1987). A list of 125 estuaries included in the U.S. inventory, including 35 GOM estuaries, is in Appendix 1. These data are occasionally revised and expanded by NOAA and are available on the internet (NOAA 1998). The data used here includes estuarine depth, area, freshwater inflow, population density (also available in Culliton et al. 1990), wetland area (also available in Field et al. 1991), average tidal range at the estuarine entrance, shellfish closure, and estuarine drainage area. Although the physical boundaries of an estuary are based on visual inspection of maps and drainage patterns, some subjective interpretations were involved that may affect the various comparisons made below (e.g., the Thousand Island area of south Florida was not subdivided into dozens of individual estuarine watersheds). The salinity for each estuary is the average salinity at the seasonal high and low discharge reported in Orlando et al. (1993) for GOM estuaries. The freshwater turnover time (sometimes called the freshwater fill time) was defined as the estuarine volume divided by the freshwater inflow $(\mathrm{d}$ $\mathrm{yr}^{-1}$ ), and was calculated to normalize estuarine turnover by drainage basin size and estuarine volume. Data on nutrient loading (Anonymous 1993) is analyzed in greater detail in Turner and Rabalais (1999). Additional information on restoration and shrimp landings are from Mathews and Minnello (1994) and Turner (1977).

\section{Description of the Gulf of Mexico}

The GOM is the earth's 5th largest sea and covers $1.5 \times 10^{6} \mathrm{~km}^{2}$ which is $60 \%$ of the size of the Atlantic Ocean (Turner 1999). It once extended northward to St. Louis, Missouri as the Mississippi Embayment. At other times it was restricted to the present-day $200 \mathrm{~m}$ isobath. Today it receives the Mississippi River, whose length, water discharge, and sediment yield are among the largest 10 rivers in the world. There are no glacial moraines or rebounding surfaces in the GOM, unlike in the northeastern U.S., but large parts of the Yucatan and Florida peninsula are calcium carbonate platforms. More than $90 \%$ of the U.S.'s offshore oil and gas reserves past production and present yields are in its coastal waters (Farrow and Broadus 1990). Its coastal waters yield about $40 \%$ of the annual U.S. fishery's tonnage and value (National Marine Fisheries Service 1987). Some GOM estuaries may be distinguished from others by: the presence of mangroves or the last significant refuges of manatees, relatively high summer temperatures and low rainfall, or a general absence of winter freezes (Fig. 1). Thirty-four million people lived in the GOM estuarine watersheds in 1990 giving rise to some of the lowest population densities among all U.S. estuaries (Fig. 2). (Note: Fig. 2 introduces the format that later figures will follow. These data and others will often be presented with the estuaries numbered from left to right on the horizontal axis, going from the Northeast U.S. to the Gulf of Mexico (numbers 56 to 90) to the Northwest. The reader should note that there are occasionally missing values and that comparable data on the estuaries of Mexico were not known to me.)

\section{Variations in Estuarine Geomorphology and Hydrology}

The average water yield $\left(\mathrm{m}^{3} \mathrm{~s}^{-1} \mathrm{~km}^{-2}\right.$ watershed), estuarine drainage area $\left(\mathrm{km}^{2}\right)$, water surface $\left(\mathrm{km}^{2}\right)$, freshwater turnover (d), and wetland: water surface ratio are shown in Fig. 3. The water yield from the watershed varies within a factor of 10 for all estuaries, except for the very dry southwest GOM and Pacific estuaries. The estuarine drainage size and water surface range over three orders of magnitude for all estuaries. Regional clusters are not evident, except for a generally smaller estuarine water surface in estuaries on the California coast.

Flushing rates are important determinants of the chemistry and biology of estuaries because, for example, of the importance to organisms with relatively short regeneration times, pollutant contact time, and to particle settling rates. The freshwater turnover rate for all estuaries ranges from 1 to $23,000 \mathrm{~d}(\mathrm{n}=105$; mean $=778)$. Table 1 presents

Fig. 1. Photographs of GOM estuaries and nearshore waters: A) Coastal Zone Color Scanner composite of phytoplankton pigment concentration (October 1978 to June 1986) from the SeaWifs (http://seawifs.gsfc.nasa.gov/SEAWIFS/CZCS_DATA). B) Turtle grass bed (Thalassia testudinum) near Vera Cruz, Mexico (N. N. Rabalais). C) Juvenile white pelican in cactus, Laguna Madre, Texas (N. N. Rabalais). D) Manatee and calf, Florida (Lockwood 1984). E) Salt marsh restoration near Tampa, before (R. Lewis). F) Salt marsh restoration near Tampa, after (R. Lewis). G) Sail fishing vessels, Laguna Madre, Tamaulipas, Mexico (N. N. Rabalais). H) Soft corals, Gulf of Mexico (N. N. Rabalais). I) Tidal flat, Upper Laguna Madre, Texas (N. N. Rabalais). J) Submerged mangrove prop roots, 

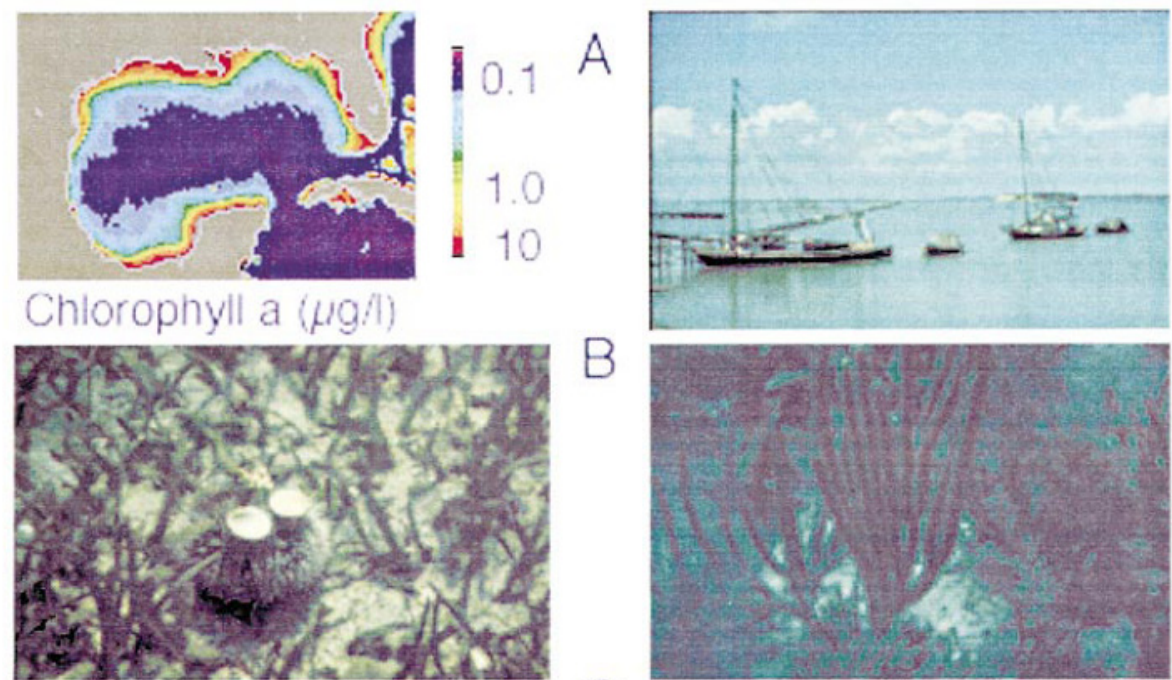

B
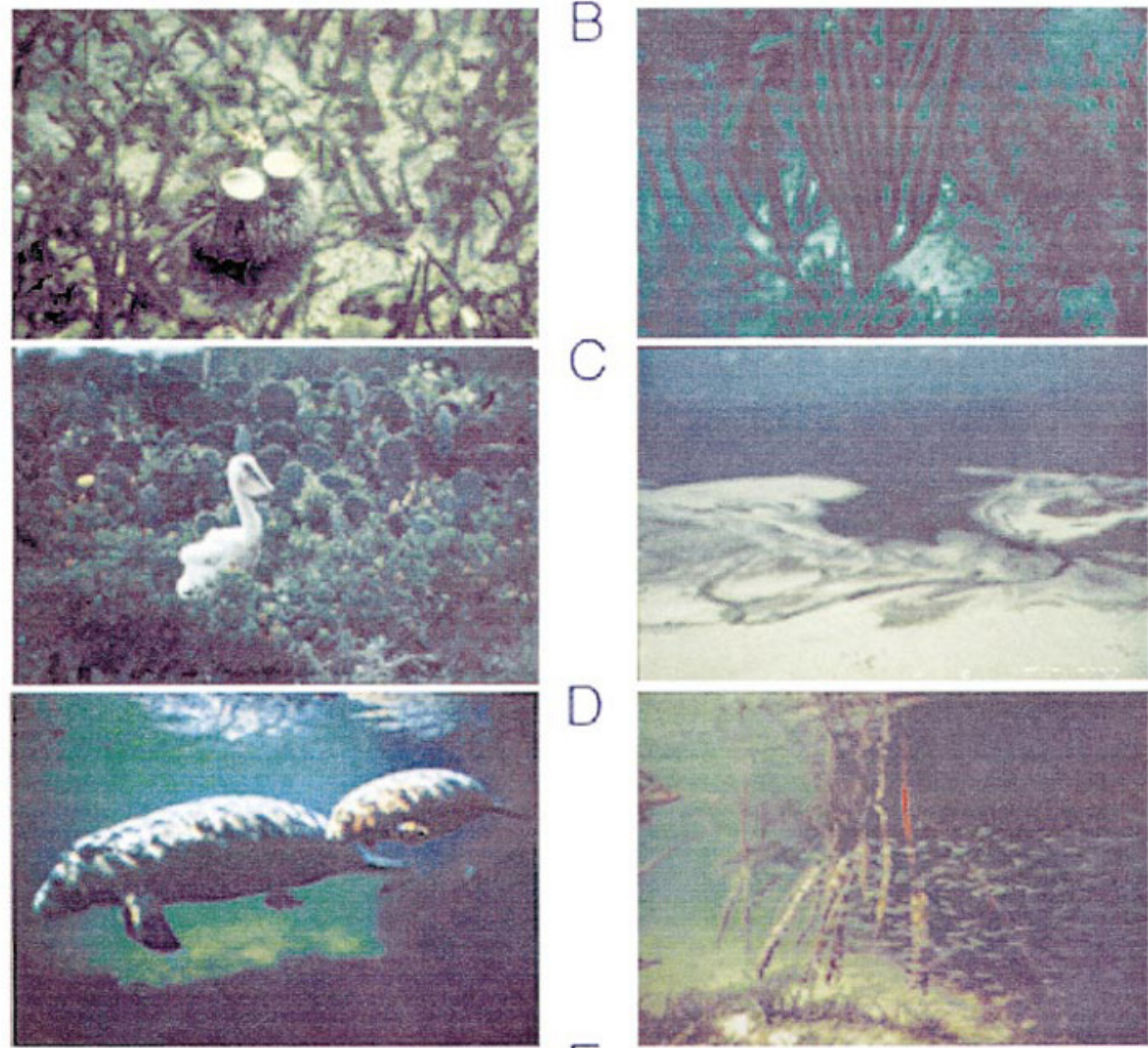

$H$

C

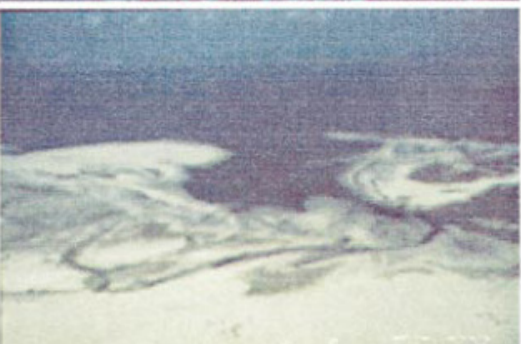

D
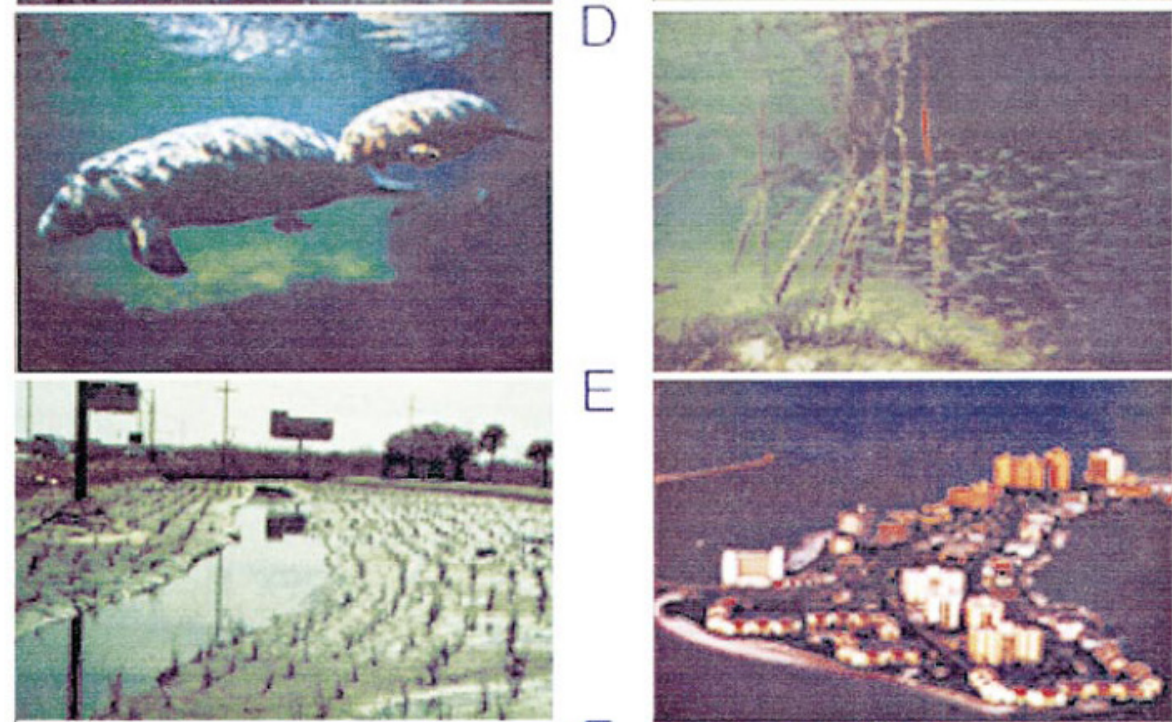

E
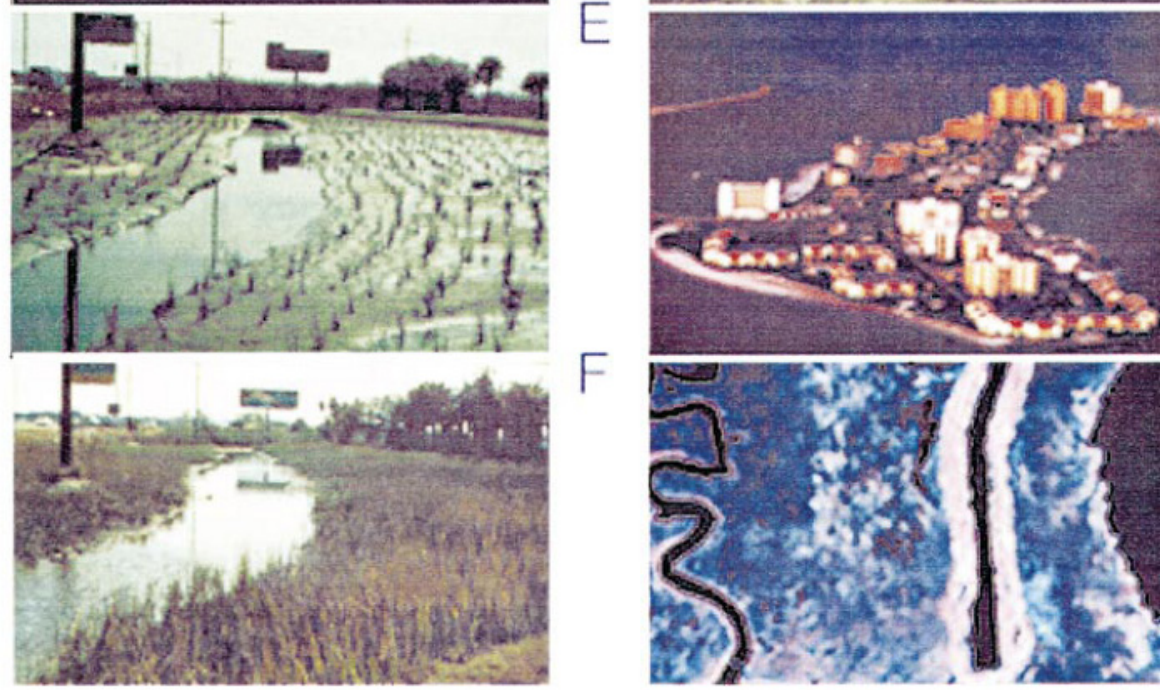

F

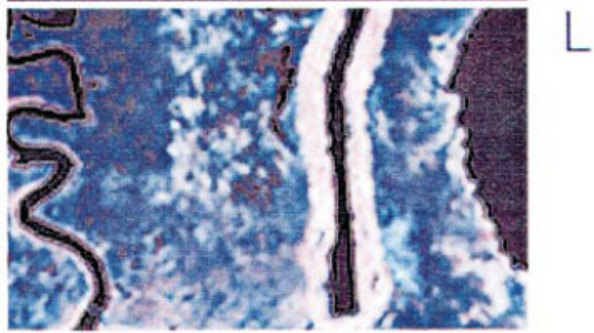

Florida (Lockwood 1984). K) Barrier island development, northwestern Florida (Lockwood 1984). L) Natural channel and dredged canal in south Louisiana (false color; 1995). 


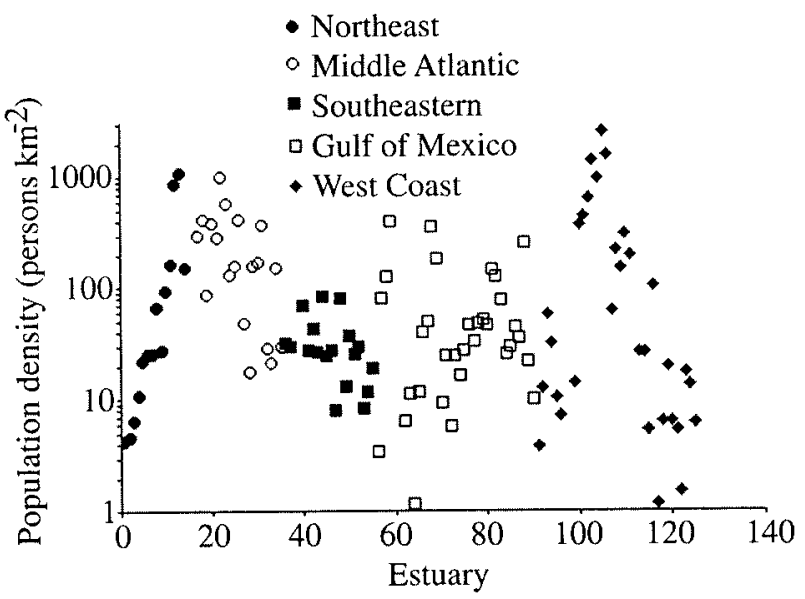

Fig. 2. The population density (persons $\mathrm{km}^{-2}$ estuarine watershed) in U.S. estuaries c. 1980. The Gulf of Mexico estuaries are numbers 56 through 90 .

the regional averages for freshwater turnover times, which average $184 \mathrm{~d}$ for $30 \mathrm{GOM}$ estuaries. The southern estuaries (GOM + Southeastern U.S), located in the middle of Fig. 3, generally have shorter freshwater turnover times than other estuaries (Table 1).

The quantity of freshwater inflow, as well as the size and shape of the receiving basin, climate, and the seaward flushing coefficients, affects estuarine salinity. Freshwater inflow in the GOM estuaries strongly influences estuarine salinity (Fig. 4), as expected. It would be interesting to compare these data with data with estuaries from macrotidal environments.

The estuarine wetland:water surface ratio is higher for the GOM estuaries compared to other regions (Fig. 3). Some of the GOM estuaries have 10 times more wetland area than water surface; a strong contrast to what happens in other estuaries. The average estuarine wetland and open water area for different regions are in Table 2. The South Atlantic and GOM estuaries each have about 28\% of the nation's coastal wetlands (note that there are data for only 81 of the 102 estuarine watersheds that were surveyed). The average size of the GOM estuarine wetland is the largest of all four regions (Table 2). The GOM has about $41 \%$ of the open water area and an above-average size.

The relationship between freshwater turnover time (d) and wetland: water surface area is shown in Fig. 5. The two variables are inversely related (note the logarithmic plot of the data). The empirical relationship is linear and improves (higher $\mathrm{r}^{2}$ ) when the lower quality data are removed, which was not done here. It suggests that if freshwater inflow were doubled, then the turnover time would be halved, and the area of wetland would be in-

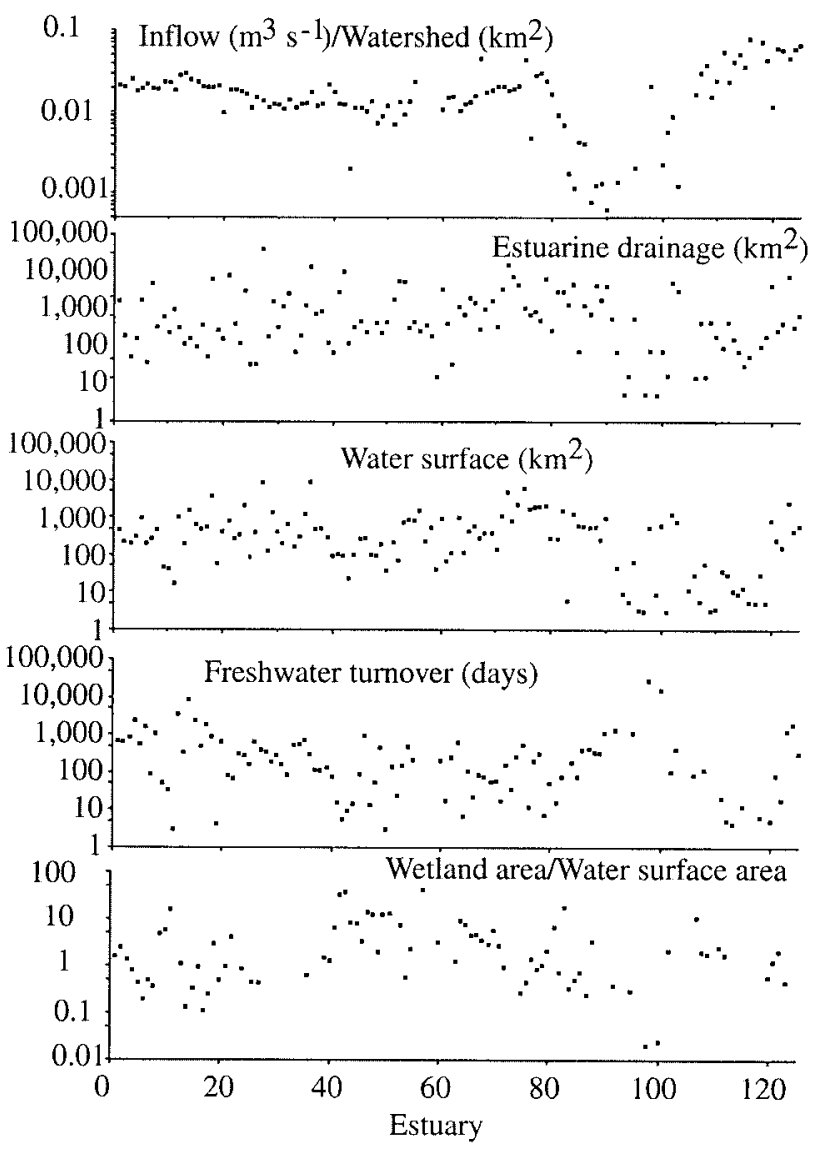

Fig. 3. Variations in U.S. estuaries, arranged from the north Atlantic (left) to the north Pacific (right). The Gulf of Mexico estuaries are numbers 56 through 90 . Shown are the values for estuarine drainage (watershed), water surface area, freshwater turnover ( = estuarine volume/freshwater inflow), and the ratio (wetland area)/(water surface area).

creased by slightly less than double. Of course, an increase in freshwater at one estuary would be matched by a decline somewhere else. This relationship reflects, I think, centuries of adjustments between watershed geomorphology and drainage characteristics. Higher freshwater inflow brings more sediments to fill the basin, increases the nutrient load, and lowers estuarine salinity. At the other end of the continuum, greater tidal energy will cause bays to deepen. Price (1947) noticed that the width of GOM estuarine bays was proportional to their depth, and called the result an equilibrium of form. I think the result in Fig. 5 also reveals another equilibrium of form, whose underlying causal mechanisms remain unclear (at least to me). In the example that Price (1947) provided, we can hypothesize that bay width determines the wind fetch, which, in turn, has a well-known influence on sediment resuspension as the effect of wind-mixing decreases with increasing water 
TABLE 1. Freshwater turnover time (estuarine volume/inflow; d) for 105 major estuaries in the U.S.

\begin{tabular}{lrc}
\hline \multicolumn{1}{c}{ Region } & Turnover & $\mathrm{n}$ \\
\hline North Atlantic & 1,323 & 14 \\
Middle Atlantic & 481 & 22 \\
South Atlantic & 147 & 19 \\
Gulf of Mexico & 184 & 30 \\
Pacific & 2,215 & 20 \\
\hline
\end{tabular}

depth. Stronger winds create proportionately stronger mixing within the water column and greater scouring. But, how much does the wetland plant distribution control the bay width? Perhaps it is the gradual encroachment of wetland plants into the estuarine bay that affects the freshwater turnover time.

Tidal amplitudes in the GOM are usually less than $1 \mathrm{~m}$, may occur once or twice daily, and change seasonally and among locations. Water levels vary daily, seasonally, over periods longer than lunar cycles, and in response to cold front passages in winter and storm events in summer. The monthly variation in sea levels throughout the Gulf of Mexico peaks in summer (Turner 1991). The highest seasonal range is in the central northern GOM. A minimum in July or August is weakly developed in Florida estuaries. Most of the monthly variation is due to changes in seawater density and atmospheric pressure changes related to the passage of winter cold fronts (Whittaker 1971). The tidal range around the U.S. coastline is greatest in higher latitudes and lowest in the Gulf of Mexico, and has a small peak in the southeastern U.S. (Fig. 6). This microtidal regime in much of the GOM is perhaps a candidate signature forcing function distinguishing these estuaries from others in the U.S.

The average estuarine depth traces a similarly shaped curve around the U.S. coastline, but with more uneven regional variability and different extremes (Fig. 7). Estuarine depth is directly related to tidal range (Fig. 8) and the GOM estuaries are clustered at the lower left in Fig. 8.

\section{Patterns in Estuarine Vegetation and Habitat in Relationship to Physical Factors}

Plants, and the habitats that plants provide, respond not only to salinity distributions, but also to

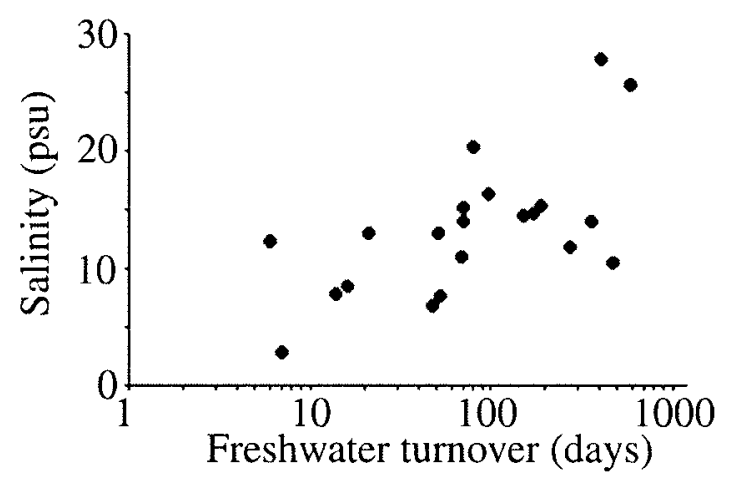

Fig. 4. The average salinity in GOM estuaries and the freshwater turnover time $(d)$.

hydrologic conditions. There is a pleasantly smooth relationship between the vertical range that salt marsh plants occupy and tidal amplitude (Fig. 9). What this relationship suggests, besides its implication to wetland loss and restoration efforts, is that the tides bring some order to estuaries. The small tidal range in GOM estuaries implies that a $10-\mathrm{cm}$ water level change may have a greater impact than a similar increment in a northeastern U.S. estuary. Water impedance and conveyance structures, for example, might have quantitatively distinct impacts micro-tidal compared to in macrotidal environments.

Redfield and Rubin (1962) and Coleman and Smith (1964), among others, have showed us that coastal salt marshes have accumulated enough material in situ to survive for the last 7,000 years in the macrotidal environments of the Bay of Fundy and the microtidal regimes of the Gulf of Mexico. This accumulation consists of both organic and inorganic material in nearly equal volume (Turner et al. 2001). The accumulation rate has varied among salt marshes and over centuries as the underlying stratum rises or sinks, or sea level changes, or because of the variability in the source materials and quantity, plant growth, belowground decomposition, and resuspension. It appears that organic matter is much more important than inorganic matter for a marsh to maintain itself once established (Turner et al. 2001). The amount organic matter contributes to vertical accretion is similar

TABLE 2. Wetland area $\left(\mathrm{km}^{2}\right)$ and open water area $\left(\mathrm{km}^{2}\right)$ for 125 major estuaries in U.S.

\begin{tabular}{|c|c|c|c|c|c|c|}
\hline \multirow[b]{2}{*}{ Region } & \multicolumn{3}{|c|}{ Wetland Area Average } & \multicolumn{2}{|c|}{ Open Water Area Average } & \multirow[b]{2}{*}{ Range } \\
\hline & $\mathrm{n}$ & (\% total) & Range & $\mathrm{n}$ & (\% total) & \\
\hline Northeast & 13 & $252(4 \%)$ & $36-616$ & 14 & $395(7 \%)$ & $16-1,419$ \\
\hline South Atlantic & 17 & $1,399(28 \%)$ & $101-4,579$ & 20 & $619(15 \%)$ & $23-7,638$ \\
\hline Gulf of Mexico & 26 & $1,654(28 \%)$ & $80-8,762$ & 35 & $945(41 \%)$ & $5-5,403$ \\
\hline Pacific & 14 & $332(6 \%)$ & $5.2-2,343$ & 33 & $236(9 \%)$ & $3-2,411$ \\
\hline All & 81 & $1,079(100 \%)$ & $5.2-8,762$ & 123 & $666(100 \%)$ & $3-9,920$ \\
\hline
\end{tabular}




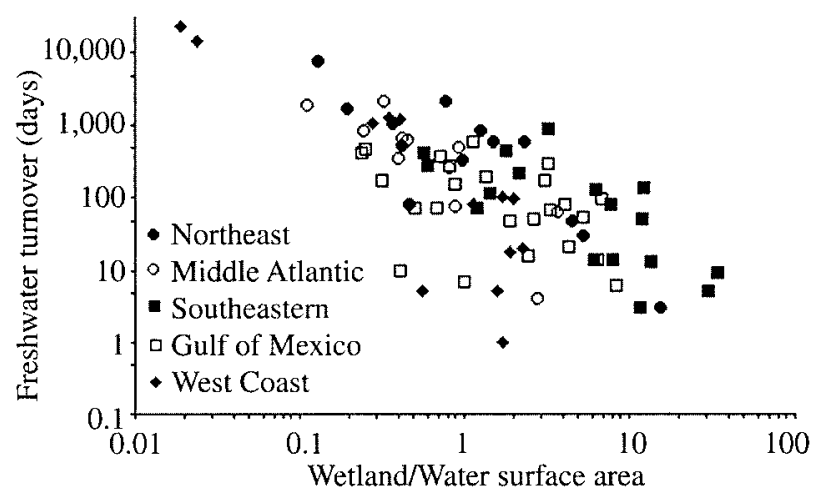

Fig. 5. The relationship between the freshwater turnover time (= inflow/estuarine volume) and the wetland: water surface area.

among U.S. salt marshes $(10.9 \mathrm{~g}$ of organic matter $=1 \mathrm{~cm}$ accretion). The organic matter accumulation rate appears to be higher in GOM estuaries compared to Atlantic coast estuaries (Fig. 10). This higher accumulation is necessary if coastal wetlands are to survive the relatively higher subsidence rates found in the GOM estuaries.

The habitat that wetlands provide juvenile fisheries species is often critical to their survival during transition into adults. Penaeid shrimp yields within the GOM estuarine regions, for example, are directly related to the area of wetlands, not open water (Fig. 11). The yield $\left(\mathrm{kg} \mathrm{ha}^{-1}\right)$ is higher towards the tropics and diminishes to zero around Virginia (Turner 1977). Penaeid shrimp are not harvested in significant quantities on the U.S. west coast.

\section{Nutrient Loadings in GOM Estuaries}

Nutrient loading to the GOM estuaries varies widely (Fig. 12). The application of fertilizer to agricultural land, an important nitrogen and phos-

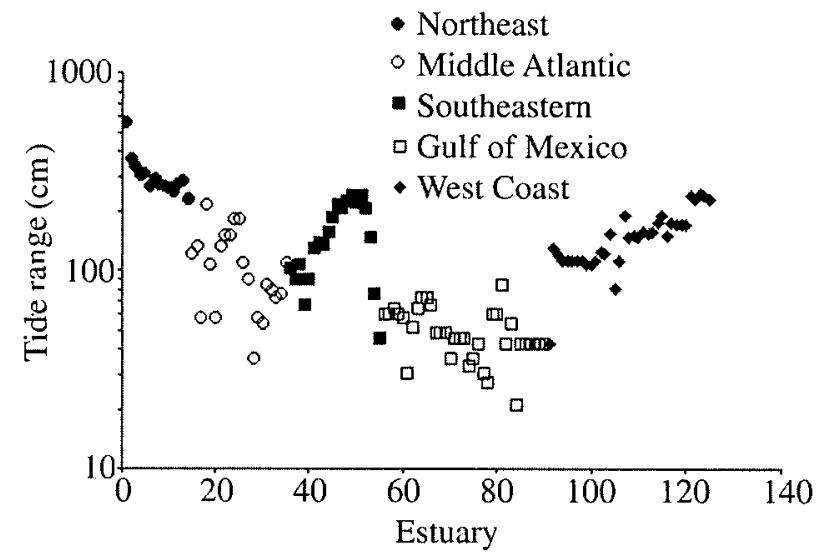

Fig. 6. The average tidal range $(\mathrm{cm})$ of U.S. estuaries at the estuarine entrance. The Gulf of Mexico estuaries are numbers 56 through 90.

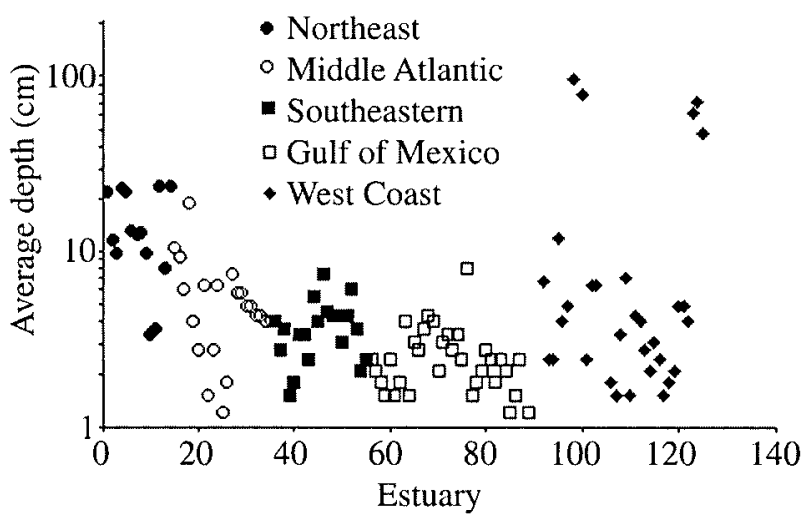

Fig. 7. The average depth $(\mathrm{m})$ of U.S. estuaries. The Gulf of Mexico estuaries are numbers 56 through 90.

phorus source, varies within a factor of 10 among GOM estuaries, as does population density. However, both nutrient loading from rivers (expressed as elemental load $\mathrm{km}^{-2}$ estuarine drainage) and the nutrient load to estuarine open water area (expressed as elemental load $\mathrm{km}^{-2}$ water surface) varies by several orders of magnitude across the GOM. This variability is, in part, due to variations in soil types, vegetation cover, water balance, the percentage of the landscape in agricultural use, nutrient sources, and the relative proportions of terrestrial, estuarine wetland, and estuarine open water.

How much of the nitrogen load remains in the estuary seems to be strongly influenced by the freshwater residence time (Fig. 13). When normalized to water turnover rates (i.e., residence times), the proportion of nitrogen loading that escapes the estuary appears to behave in a manner that is similar to that in non-GOM estuaries. The total load and residence time will clearly influence estuarine plant production, whose consumption in stratified bottom waters will contribute to low oxygen levels. Hypoxic water formation $\left(<2 \mathrm{mg} \mathrm{l}^{-1}\right)$ sometimes occurs in GOM estuaries. Its occur-

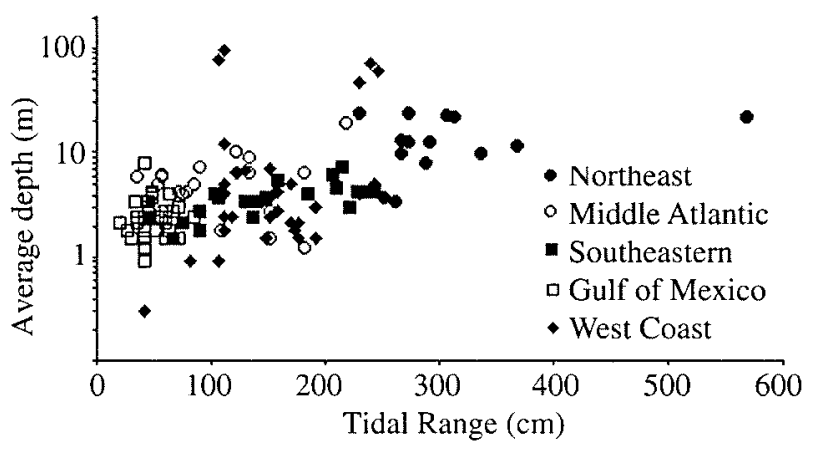

Fig. 8. The relationship between the average tidal range $(\mathrm{cm})$ and depth of U.S. estuaries. 


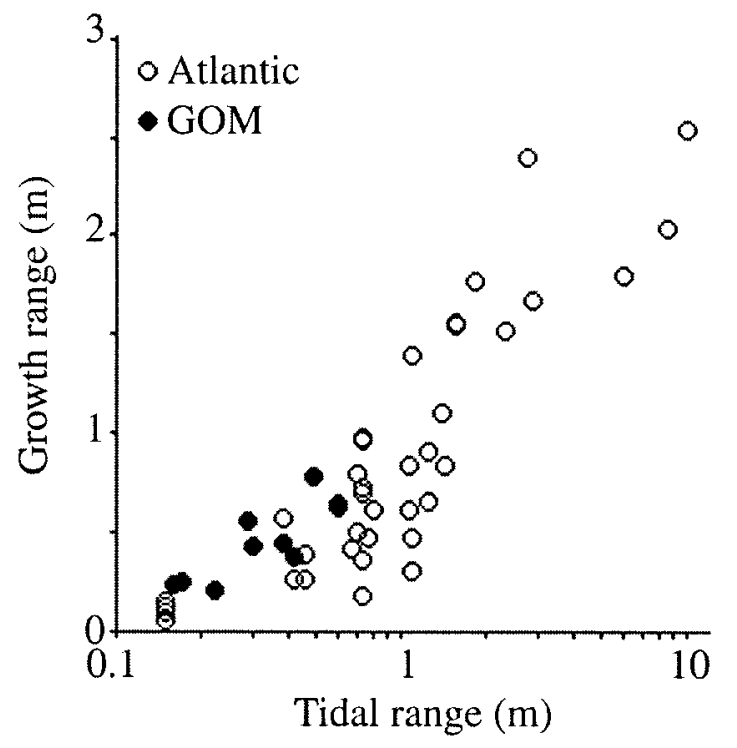

Fig. 9. The relationship between the growth range of Spartina alterniflora and tidal rage (adapted from Lodrigue and Turner in review).

rence is most likely to occur in estuaries with higher nutrient loading and whose freshwater inflow is small relative to estuarine volume (Turner and Rabalais 1999).

\section{Landscape Influences in the GOM Estuaries: Research Questions}

Estuaries, like lakes, are responsive to the influence of the surrounding landscape. Hutchinson (1936 p. 99) made some relevant comments about the interactions between landscape and lakes in Tibet, that may seem even more appropriate, if you exchange "lake" with "estuary":

"Each shade of blue or green sums up in itself a structure and a history, for each lake is a small world, making its nature known to the larger world ... most clearly in its colour. These little worlds of turquoise, set among red, brown, grey and white rocks, are not independent of the dry landscape around them ..... In the quality of this scene, accentuated by the foetid sulphurous water that lies at the bottom of the lake, may be traced the whole life of the surrounding country."

The quality of upstream water, which affects both estuarine and lacustrine primary production, is largely determined by land use, climate, and geology. Less obvious, but significant, influences on estuarine functions are the size, shape, and proportions of landscape features within the drainage basin and the estuary. The fisheries: wetland couplings shown in Fig. 11 are but an end-result of

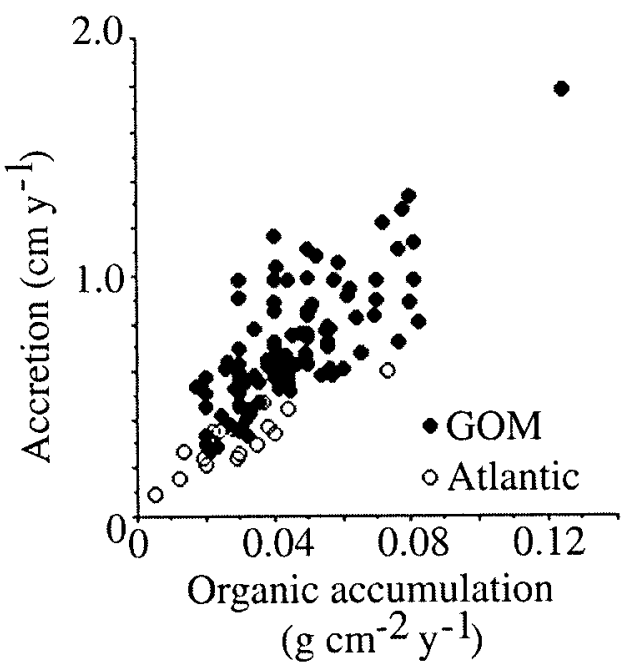

Fig. 10. The relationship between the organic accumulation $\left(\mathrm{g} \mathrm{cm}^{-2} \mathrm{yr}^{-1}\right)$ and accretion rate $\left(\mathrm{cm} \mathrm{yr}^{-1}\right)$ for 141 salt marshes in the GOM and Atlantic estuaries where Spartina alterniflora is found (adapted from Turner et al. 2001).

multiple interacting and controlling factors. I will give a few examples here from GOM estuaries, and make some suggestions for research scientists to address to help the future conservation of these systems.

The distribution of animal and plant species richness with area is widely documented for terrestrial systems, but not for estuarine systems. Neill and Deegan (1986) found that habitat richness increased as the area of the Mississippi Deltaic Plain deltaic lobe increased, regardless of when the initial lobe formed. This pattern is what we would expect from the theory and observations known as island biogeography (MacArthur and Wilson 1967). It would be useful for management and restoration interests to know if these area:species patterns are generally true for the aquatic estuarine community, or the wetland plant community, so

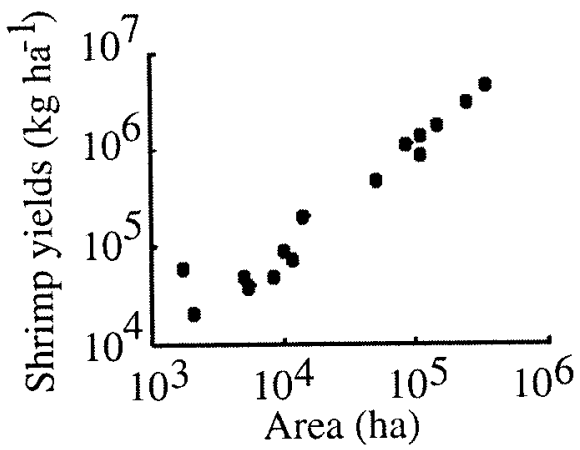

Fig. 11. The relationship between intertidal vegetation and penaeid shrimp yields from the estuaries of the northern Gulf of Mexico (adapted from Turner 1977). 


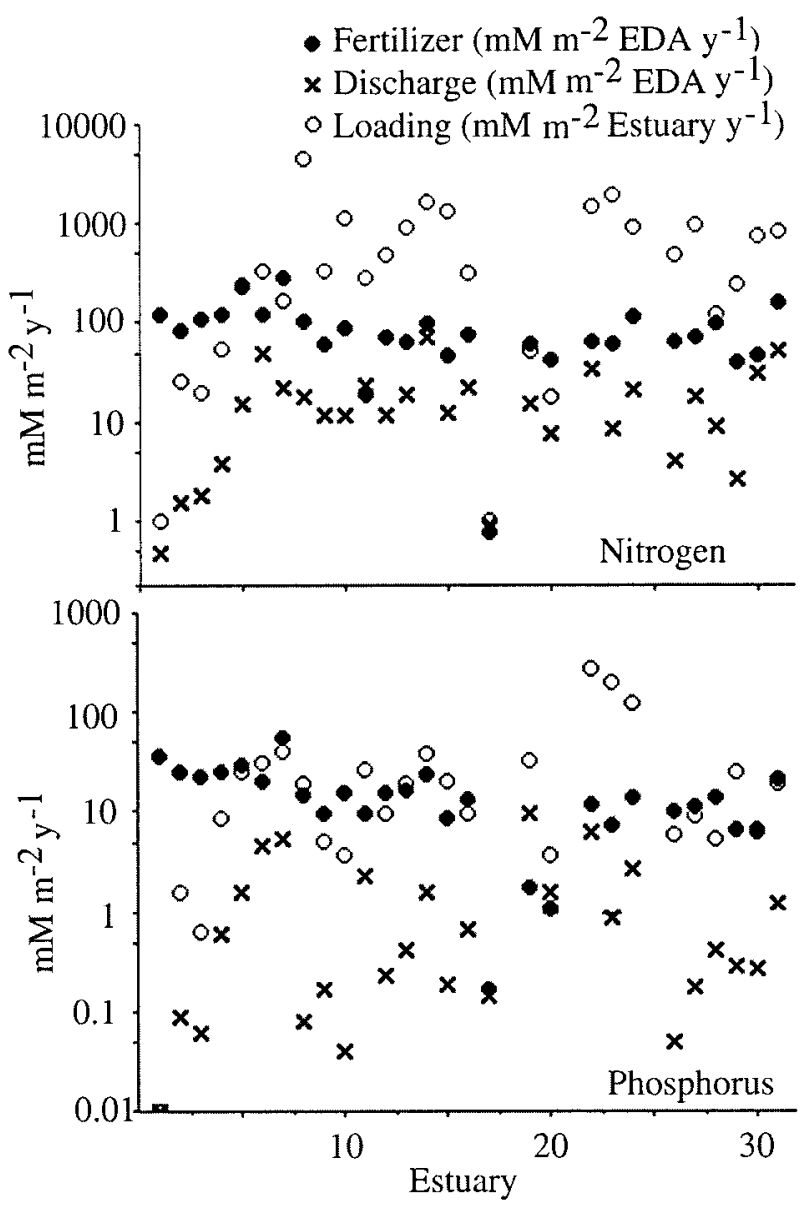

Fig. 12. Nitrogen and phosphorus loading to GOM estuaries. The closed circle is the nutrient loading of fertilizer per estuarine drainage area. The $\mathrm{X}$ is the nutrient discharge per estuarine drainage area. The open circle is the nutrient loading per area of estuarine surface.

that conservation easements, restoration and development projects, and cumulative impacts might be more effectively evaluated.

Waterfowl harvest and management is often a strong influence on wetland management. Many coastal waterfowl management plans are structured in a way to replicate the experience of freshwater systems, and to optimize the amount of open water (often at an open water:marsh ratio of 1:1). The ratio of wetland:open water area in freshwater marshes has an effect on avian species richness (e.g., Weller and Fredrickson 1974; Brown and Dinsmore 1986), but we do not know if these patterns hold for estuarine systems, if they have too salty or have too little or too much edge, or if other factors are at work. It would be useful to know the underlying ecological processes at work that substantiate these management choices, or, if the experience from freshwater system is misapplied. The GOM estuaries are the location of many over-win-

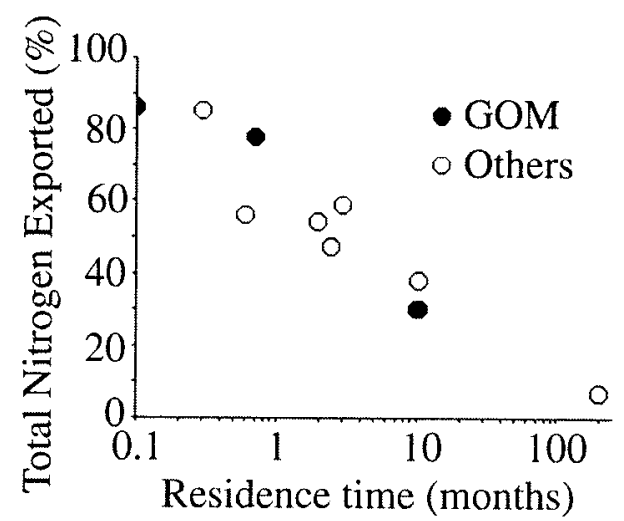

Fig. 13. The relationship between the residence time and nitrogen retention in GOM and other estuaries (from Nixon et al. 1996).

ter waterfowl refuges and offer diverse environments to examine these questions in a comparative way, and to learn if these relationships hold for other organism groupings. The effect of different water: wetland ratios must also affect water quality where wetlands transform nutrients and the freshwater flushing time is changed. A comparison of data from many estuaries would help tease out key coefficients useful to understanding landscape changes.

Childers et al. (1999) reviewed 52 data sets to examine the effects of various landscape characteristics on nutrient exchanges between estuarine wetland and tidal waters in the Gulf of Mexico. They found no significant difference in exchanges between water column and wetlands for mangrove and herbaceous vegetation types. In contrast to this result, however, they did conclude that the ammonia was taken up in carbonate systems and exported in terrigenous-clastic systems. Wetlands near open water and with "minimal couplings to their upstream watersheds" (Childers et al. 1999 p. 232) exported DOC and imported POC and PON $(\mathrm{DOC}=$ dissolved organic carbon; $\mathrm{POC}=$ particulate organic carbon; $\mathrm{PON}=$ particulate organic nitrogen). Wetlands embedded within a larger wetland landscape imported DOC and released POC and PON. If the exchange of inorganic and organic forms is affected by the landscape setting, then perhaps the pelagic food web, the benthic community, and fish recruitment is also affected.

These questions are focused on plant habitats, animal distribution, and chemical exchanges between water column and wetland. There is no apparent regional signature to the estuarine landscape as measured by geomorphic criteria (e.g., Fig. 3), so it is difficult to conclude that regional landscape influences are distinctively different. 


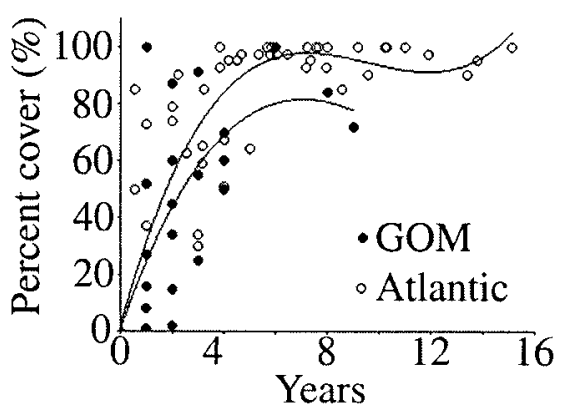

Fig. 14. The relationship between the restoration rate (measured as plant cover) and time since initiation of salt marsh and mangrove marsh creation and restoration for projects from the GOM and Atlantic. The data are from Mathews and Minello (1994). A third degree polynomial of the data is shown for each data set $\left(\right.$ GOM \% Cover $=0.4+26.5 \mathrm{x}-2.6 \mathrm{x}^{2}+0.07 \mathrm{x}^{3}, \mathrm{n}=$ $89, \mathrm{r}^{2}=0.74 ;$ Atlantic $\%$ Cover $=1.7+33.4 \mathrm{x}-3.7 \mathrm{x}^{2}+0.13 \mathrm{x}^{3} \mathrm{n}$ $\left.\mathrm{n}=113, \mathrm{r}^{2}=0.92\right)$.

But, perhaps this will be shown otherwise with more data and further analysis.

\section{Estuarine Restoration in the GOM}

The effects of modern culture, of course, have altered the natural landscape and ecological relationships in ways that we can sometimes see all too clearly, and also in very subtle ways. Exemplars of these effects can be seen in the GOM for wetlands, nutrients, and water quality.

The GOM has a relatively high net loss of coastal wetlands compared to other regional groupings and there are administrative programs and both restoration and mitigation projects to avoid wetland loss in all GOM states. The vast majority of the coastal wetland losses in the U.S. this century were in the GOM, principally in Louisiana (Dahl 1990). A case can be made that the primary reason for these losses is the indirect consequences of hydrologic change following dredging (Turner 1997), but this is not a consensus view of all wetland scientists (Day et al. 2000). Hydrologic changes have caused wetland losses throughout the world and the re-establishment of the natural hydrology has been attempted as part of restoration (e.g., Turner and Lewis 1996). Louisiana, for example, has an ambitious federal-state coastal restoration plan whose last 5 year budget was $\$ 226$ million. The uniquely high wetland losses and attempts to address them are the result of variations in the cultural, not natural setting.

It would be useful for estuarine managers to know if wetland restoration rates vary among estuaries in order to plan, allocate resources and effectively evaluate projects. Mathews and Minello (1994) reviewed the mostly unpublished literature to summarize the recovery. An analysis of their data (Fig. 14) shows that the recovery rate, aver- aging $60 \%$ to $80 \%$ cover in 4 years, was no faster in GOM wetlands than in Atlantic coastal wetlands.

Estuarine eutrophication has long been viewed as a general threat to estuarine and coastal water health and is well-documented in the GOM (Rosenberg 1985; Rabalais 1992). The largest offshore hypoxic zone in the U.S. is near the Mississippi River delta. The distribution, size, and severity of this zone is directly related to the river's nitrogen loading which dramatically increased this century (from land use changes in the Midwest; Rabalais et al. 1996).

Examples of successful water quality restoration, however, are hard to come by. Two examples come from the GOM. The seagrasses of Tampa Bay were reduced to $20 \%$ of the areal coverage of 100 years ago when improvements in water quality began around 1984 (Johansson and Lewis 1992). The submerged macrophyte cover (seagrasses) in Hillsborough Bay and Middle Tampa Bay doubled from 1986 to 1989 , and is continuing to improve into the late 1990s (Lewis personal communication). The eutrophication of Bayou Texar, near Pensacola, Florida, was studied by Moshiri et al. (1981) to determine the causes and remedies for extensive fish kills (lasting up to $5 \mathrm{wk}$ ), closure to recreational use, noxious algal blooms, and high algal biomass, which contributed to low dissolved oxygen levels. A retention reservoir and weirs in the upstream channels were built in 1974, and sewage plants were repaired. The authors reported an almost total reduction in fish kills, a $90 \%$ reduction in phytoplankton primary production, and a virtual elimination of algal blooms. Public use of the estuary then resumed.

\section{The Need for Field-Based Estuarine Comparisons}

The physics, chemistry, geology, and biology of estuaries vary greatly. This variability provides a means to investigate fundamental interactions so that the underlying processes and linkages developed in a few estuaries can be applied to the many estuaries. An efficient mechanism to achieve this goal is to make comparable measurements of key parameters in many estuaries representing this variability. It would be important to capture as wide a range in estuarine variability as possible in such a study to improve the predictive abilities. The present number of National Science Foundation Long-term Ecological Research and Land Margins Ecological Research sites, for example, are insufficiently small to do this, in my opinion, and additional protected sites (e.g., National Estuarine Research Reserves) were chosen for other reasons. A field-based, cross-system comparison of estuaries that examines different landscape scales, ages, and vegetation types, etc., will further reveal the 
strength of these bio-geo-physico-chemical interactions. Important physical parameters to consider are wave energy, freshwater turnover times, size, watershed morphology, and water column stratification. For example, the effects of watershed size on estuarine flushing is important to understand because of the many consequences to chemical pathways, sediment accumulation and erosion, biological growth and mortality, and nutrient loading rates. Important biological parameters include wetland: water ratios, landscape mosaics (fragmentation, source materials, and composition), nutrient loading rates, light regime, and couplings with upstream and continental shelf systems. A crosssystem comparison would be useful to determine how variable estuarine flushing rates (from freshwater and seaward end-member) structure the material flows within and through estuaries, the roles that the coastal boundary layer plays in introducing materials from the sea into the estuaries (especially nutrients limiting phytoplankton growth), and the effect of various projected or likely land use and climate changes will have on estuarine inflow rates and constituent concentrations.

Some patterns are apparent. For example, if estuarine vegetation fills in open water areas and bays, then the freshwater turnover time will increase and salinity will change. Estuaries with the longest water turnover time and the high nutrient loading rates are most susceptible to phytoplankton bloom formations. The idea here is that quantification of these relationships is now neither sufficient nor predictable, and that this situation would be improved by comparative analyses.

Accomplishing this goal would quickly have many social benefits. Humans influence the quality of almost all landscapes and estuaries have not escaped these influences. Estuaries are already used and managed heavily for resource harvests, habitation, and recreation. One example of these stressors can be demonstrated by the widespread closure of shellfish beds. One third of the shellfish beds in the U.S. were closed to harvest in the 1980 s, and there was total closure for some estuaries in all regions (Fig. 15). Population re-distribution and growth will only become more significant in the next few decades. The effects of the anticipated changes in estuarine temperature and freshwater inflow, as well as accelerated sea level rise, add confounding dimensions to our predicative capabilities. The underlying assumption of this analysis is that this variability can be understood, is worth knowing, and that our knowledge of these processes can be improved in the next decade with a reasonable effort.

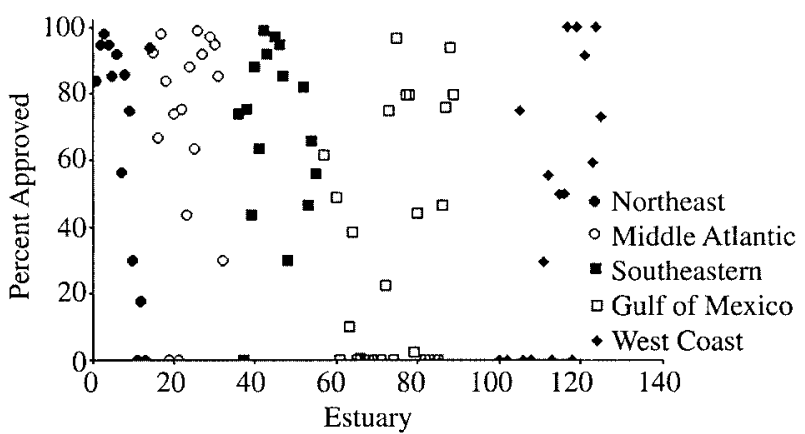

Fig. 15. The fraction of approved shellfish beds in U.S. estuaries c. 1980. The Gulf of Mexico estuaries are numbers 56 through 90 .

\section{Are Gulf of Mexico Estuaries Unique?}

The variability of key geomorphological features (e.g., estuarine width, depth, flushing, wetland area), nutrient loading, and economic development among U.S. estuaries is very large, often spanning several orders of magnitude (Figs. 2, 3, 8 , and 13). Compared to other regional estuarine groupings, the average GOM estuary is distinguished by being shallower, having faster freshwater flushing time (Table 1), more wetland per open water area (Fig. 3), greater fisheries yield per area wetland, lower tidal range (Fig. 6), and higher sedimentation rates (Fig. 10). Some GOM estuaries have flora and fauna not usually found in most other U.S. estuaries (e.g., manatees and mangroves) or even in other GOM estuaries. The Mississippi River, a uniquely large, world-class river, dominates the freshwater and nutrient inflows to the GOM continental shelf. In contrast to these distinctions, the variations in several indicators of nutrient loading (Fig. 12) and population density (Fig. 2) are large enough to demonstrate that there are no systematic differences among these estuarine regions which precludes cross-system analyses. For example, there is obvious discontinuity in the relationship between some fisheries yields and wetland area (Turner 1977), tide range (Fig. 6) and vegetation distribution (Fig. 9), salt marsh accretion rates and organic accumulations (Fig. 10), nitrogen retention (Fig. 13), or restoration rates (Fig. 14) among these regional groupings. These results suggest that a comparative analysis emphasizing forcing functions, rather than geographic uniqueness, will lead to significant progress in understanding how all estuaries function, are perturbed, and even how they can be restored.

This analysis started with the question: Are GOM estuaries unique? The microtidal regime is one physical factor common to all GOM estuaries that distinguishes them from most other U.S. estuaries. Most other factors examined, however, demon- 
strate a widely varying range of values among regional groupings. Perhaps this question is too involved in issues involving classification, and we should instead be asking about how to effectively build understanding of the fundamental interactions giving rise to this variation.

\section{ACKNOWLEDGMENTS}

The Gulf Estuarine Research Society and the Governing Board of the Estuarine Research Federation initiated this series of comparative papers on regional estuaries, whose shortcomings, of course, are not theirs to assume. Comments made by the other authors in this series of papers, unidentified reviewers, J. Cable, G. Harris, and J. Kastler are very much appreciated. E. K. H. Turner and N. N. Rabalais offered encouragement and patience during the very pleasant field trips in Florida where the initial formal writing began.

\section{Literature Cited}

ANONYMOus. 1993. Nutrient Enrichment Potential Watershed Assessment and Comparison (NEPWAC) System Gulf of Mexico Component, Ver. 1.0. Pollution Sources Characterization Branch, National Oceanic and Atmospheric Administration, for the U.S. Environmental Protection Agency's Gulf of Mexico Program, Stennis Space Center, Stennis, Mississippi.

BRown, M. AND J. J. DinSMORE. 1986. Implications of marsh size and isolation for marsh bird management. Journal of Wildlife Management 50:392-397.

Childers, D. L., S. E. Davis III, R. Twilley, ANd V. Rivera-MonROY. 1999. Wetland-water column interactions and the biogeochemistry of estuary-watershed coupling around the Gulf of Mexico, p. 211-235. In T. S. Bianchi, J. R. Pennock, and R. W. Twilley (eds.), Biogeochemistry of Gulf of Mexico Estuaries. J. Wiley \& Sons, Inc., New York.

Coleman, J. M. And W. G. Smith. 1964. Late recent rise of sea level. Geological Society America Bulletin 75:833-840.

Culliton, T. J., M. A. Warren, T. R. Goodspeed, D. G. Remer, C. M. Blackwell, and J. J. MCDonough III. 1990. 50 Years of Population Change along the Nation's Coasts 1960-2010. Strategic Assessment Branch, Ocean Assessments Division, Office of Oceanography and Marine Assessment, National Ocean Service, National Oceanic and Atmospheric Administration, Rockville, Maryland.

DAHL, T. E. 1990. Wetland Losses in the United States 1780s to 1980s. U.S. Department of Interior, Fish and Wildlife Service. Washington, D.C.

Day, J. W., G. P. Shaffer, L. D. Britsch, D. J. Reed, S. R. Hawes, AND D. CAHOON. 2000. Pattern and process of land loss in the Mississippi Delta: A spatial and temporal analysis of wetland habitat change. Estuaries 23:425-438.

FARrow, R. S. AND J. BROAduS. 1990. Managing the Outer Continental Shelf Lands: Oceans of Controversy. Taylor and Francis, New York.

Field, D. W., A. J. Reyer, P. V. Genovese, and B. D. Shearer. 1991. Coastal Wetlands of the United States: An Accounting of a Valuable National Resource. Strategic Assessment Branch, Ocean Assessments Division, Office of Oceanography and Marine Assessment, National Ocean Service, National Oceanic and Atmospheric Administration, Rockville, Maryland in cooperation with National Wetlands Inventory, Fish and Wildlife Service, U.S. Department of the Interior, Washington, D.C. and the National Wetlands Research Center, Fish and Wildlife Service, U.S. Department of the Interior, Slidell, Louisiana.

Howarth, R. W., G. Billen, D. Swaney, A. Townsend, N. Jaworski, K. Lajtha, J. A. Downing, R. Elmgren, N. Caraco, T. Jordan, F. Berendse, J. Freney, V. Kudeyarov, P. Murdoch,
AND Z. ZHAO-LIANG. 1996. Regional nitrogen budgets and riverine N \& P fluxes for the drainages to the North Atlantic Ocean: Natural and human influences. Biogeochemistry 35:75139.

Hutchinson, G. E. 1936. The Clear Mirror. Leete's Island Books, New Haven, Connecticut.

Johansson, J. O. R. AND R. R. LewIS III. 1992. Recent improvements of water quality and biological indicators in Hillsborough Bay, a highly impacted subdivision of Tampa Bay, Florida, U.S.A., p. 1199-1215. In R. A. Vollenweider, R. Marchetti, and R. Viviani (eds.), Marine Coastal Eutrophication, Elsevier, New York.

Lockwood, C. C. 1984. Gulf Coast: Where Land Meets the Sea. Louisiana State University Press, Baton Rouge, Louisiana.

LODRIGUE, K. AND R. E. TURNER. In review. The relationship of Spartina alterniflora growth range to mean tide range. Wetlands Ecology and Management.

MacArthur, R. H. and E. O. Wilson. 1967. The Theory of Island Biogeography. Princeton University Press, Princeton, New Jersey.

Mathews, G. A. and T. J. Minello. 1994. Technology and Success in Restoration, Creation, and Enhancement of Spartina alterniflora Marshes in the United States. Volume 2. Inventory and Human Resources Directory. National Oceanic and Atmospheric Administration Coastal Ocean Program, Decision Analysis Series No. 2. U.S. Department of Commerce, Washington, D.C.

Moshiri, G. A., N. G. Aumen, And W. B. Crumpton. 1981. Reversal of the eutrophication process: A case study, p. 373-390. In B. J. Neilson and L. E. Cronin (eds.), Estuaries and Nutrients. Humana Press, Inc., Clifton, New Jersey.

National Marine Fisheries Service. 1987. Fisheries of the United State, 1986. Current Fisheries Statistics No. 8385. U.S. Department of Commerce, National Oceanic and Atmospheric Administration, Washington, D.C.

Neill, C. And L. A. DeEgan.1986. The effect of Mississippi River delta lobe development on the habitat composition and diversity of Louisiana coastal wetlands. American Midland Naturalist 116:296-303.

Nixon, S. W. 1979. Between coastal marshes and coastal waters-A review of twenty years of speculation and research on the role of salt marshes in estuarine productivity and water chemistry, p. 437-525. In P. Hamilton and K. B. Macdonald (eds.), Estuarine and Wetland Processes. Plenum Press, New York.

Nixon, S. W. 1992. Coastal marine eutrophication: A definition, social causes, and future concerns. Ophelia 41:199-219.

Nixon, S. W., J. W. Ammerman, L. P. Atkinson, V. M. Berounsky, G. Billen, W. C. Boicourt, W. R. Boynton, T. M. Church, D. M. Ditoro, R. Elmgren, J. H. Garber, A. E. Giblin, R. A. Jahnke, N. J. P. Owens, M. E. Q. Pilson, and S. P. Seitzinger. 1996. The fate of nitrogen and phosphorus at the land-sea margin of the North Atlantic Ocean. Biogeochemistry 35:141180.

NATional Oceanic and Atmospheric Administration. 1998. Coastal Assessment and Data Synthesis System. Online database of estuarine and watershed physical and hydrological characteristics, eutrophication condition information, nutrient loadings, land use. http://cads.nos.noaa.gov.

Orlando, Jr., S. P., L. P. Rozas, G. H. Ward, and C. J. Klein. 1993. Salinity Characteristics of Gulf of Mexico Estuaries. National Oceanic and Atmospheric Administration, Office of Ocean Resources Conservation and Assessment, Silver Spring, Maryland.

PRICE, W. A. 1947. Equilibrium of form and forces in tidal basins of the coast of Texas and Louisiana. Bulletin American Association of Petroleum Geologists 31:1619-1663.

Rabalais, N. N. 1992. An Updated Summary of Status and Trends in Indicators of Nutrient Enrichment in the Gulf of 
Mexico. Report to Gulf of Mexico Program, Nutrient Enrichment Subcommittee. Publ. No. EPA/800-R-92-004, U.S. Environmental Protection Agency, Office of Water, Gulf of Mexico Program, Stennis Space Center, Mississippi.

Rabalais, N. N., R. E. Turner, D. Justic, Q. Dortch, W. J. Wiseman, JR., AND B. SEn Gupta. 1996. Nutrient changes in the Mississippi River and system responses on the adjacent continental shelf. Estuaries 19:386-407.

REDField, A. C. AND M. Rubin. 1962. The age of salt marsh peat and its relation to recent changes in Barnstable Harbor, Massachusetts. Proceedings of the National Academy of Sciences 48: $1728-1735$.

RosenBERG, R. 1985. Eutrophication-The future marine coastal nuisance? Marine Pollution Bulletin 16:227-231.

Strategic Assessment BRANCH. 1985. National Estuarine Inventory: Data Atlas, Volume 1: Physical and Hydrologic Characteristics. Strategic Assessment Branch, Ocean Assessments Division, National Ocean Service, National Oceanic and Atmospheric Administration, Rockville, Maryland.

StRAtegic Assessment BRANCH. 1987. National Estuarine Inventory: Data Atlas, Volume 2: Land Use Characteristics. Strategic Assessment Branch, Ocean Assessments Division, National Ocean Service, National Oceanic and Atmospheric Administration, Rockville, Maryland.

TURNER, R. E. 1977. Intertidal vegetation and commercial yields of penaeid shrimp. Transactions of the American Fisheries Society 106:411-416.

TURNER, R. E. 1991. Tide gage records, water level rise and subsidence in the northern Gulf of Mexico. Estuaries 14:139-147.

TURNER, R. E. 1997. Wetland loss in the northern Gulf of Mexico: Multiple working hypotheses. Estuaries 20:1-13.

TuRner, R. E. 1999. Inputs and outputs of the Gulf of Mexico, p. 64-73. In H. Kumpf, K. Steidinger, and K. Sherman (eds.), The Gulf of Mexico Large Marine Ecosystem. Blackwell Science, Oxford, United Kingdom.

TURNER, R. E. AND R. R. LEWIS III. 1996. Hydrologic restoration of coastal wetlands. Wetlands Ecology and Management 4:65-72.

Turner, R. E. AND N. N. Rabalais. 1999. Suspended particulate and dissolved nutrient loadings to Gulf of Mexico estuaries, p. 89-107. In T. S. Bianchi, J. R. Pennock, and R. W. Twilley (eds.), Biogeochemistry of Gulf of Mexico Estuaries. J. Wiley \& Sons, Inc., New York.

Turner, R. E., E. M. Swenson, and C. S. Milan. 2001. Contrasting organic and inorganic content in recently accumulated salt marsh sediments. In M. Weinstein and D. D. Kreeger (eds.), Concepts and Controversies in Tidal Marsh Ecology. Kluwer Academic Publishers, Dordrecht, The Netherlands. In press.

Weller, M. W. ANd L. H. Fredrickson. 1974. Avian ecology of a managed glacial marsh. Living Bird 12:269-291.

WhitAKer, R. E. 1971. Seasonal Variations of Steric and Recorded Sea Level of the Gulf of Mexico. Office of Naval Research Contract Rept. N00014-68-A-0308-0002. Ref. 71-14T. Texas A\&M University, College Station, Texas.

\section{SOURCE OF UnPublished MATERIALS}

LEwIS, R. personal communication. Lewis Environmental Services, Inc., P. O. Box 400, Ruskin, Florida 33570-0400.

Received for consideration, January 16, 1999

Accepted for publication, November 28, 2000
Appendix 1. The estuarine drainage areas included in this analysis.

\begin{tabular}{|c|c|c|c|}
\hline & NORTH ATLANTIC & 61 & Caloosahatchee River \\
\hline 1 & Passamaquoddy Bay & 62 & Sarasota Bay \\
\hline 2 & Englishman Bay & 63 & Tampa Bay \\
\hline 3 & Narraguagus Bay & 64 & Suwannee River \\
\hline 4 & Blue Hill Bay & 65 & Apalachee Bay \\
\hline 5 & Penobscot Bay & 66 & Apalachicola Bay \\
\hline 6 & Muscongus Bay & 67 & St. Andrew Bay \\
\hline 7 & Sheepscot Bay & 68 & Choctawhatchee Bay \\
\hline 8 & Casco Bay & 69 & Pensacola Bay \\
\hline 9 & Saco Bay & 70 & Perdido Bay \\
\hline 10 & Great Bay & 71 & Mobile Bay \\
\hline 11 & Merrimack River & 72 & Mississippi Sound \\
\hline 12 & Massachusetts Bay & 73 & Lake Borgne \\
\hline 13 & Boston Bay & 74 & Lake Pontchartrain \\
\hline 14 & Cape Cod Bay & 75 & $\begin{array}{l}\text { Breton/Chandeleur } \\
\text { Sounds }\end{array}$ \\
\hline & MIDDLE ATLANTIC & 76 & Mississippi River \\
\hline 15 & Buzzards Bay c & 77 & Barataria Bay \\
\hline 16 & Narragansett Bay c & 78 & Terrebonne/Timbalier \\
\hline 17 & Gardiners Bay & & Bays \\
\hline 18 & Long Island Sound c & 79 & Atchafalaya/Vermilion \\
\hline 19 & Connecticut River & & Bays \\
\hline 20 & Great South Bay & 80 & Calcasieu Lake \\
\hline 21 & Hudson River/Raritan Bay & 81 & Sabine Lake \\
\hline 22 & Barnegat Bay & 82 & Galveston Bay \\
\hline 23 & New Jersey Inland Bays & 83 & Brazos River \\
\hline 24 & Delaware Bay & 84 & Matagorda Bay \\
\hline 25 & Delaware Inlkand Bays & 85 & San Antonio Bay \\
\hline 26 & Chincoteague Bay & 86 & Aransas Bay \\
\hline 27 & Chesapeake Bay & 87 & Corpus Cristi Bay \\
\hline 28 & Patuxent River & 88 & Upper Laguna Madre \\
\hline 29 & Potomac River & 89 & Baffin Bay \\
\hline 30 & Rappahannock River & 90 & Lower Laguna Madre \\
\hline 31 & York River & & \\
\hline 32 & James River & & PACIFIC \\
\hline 33 & Chester River & 91 & Tijuana Estuary \\
\hline 34 & Choptank River & 92 & San Diego Bay \\
\hline 35 & Tangier/Pocomoke Sounds & 93 & Mission Bay \\
\hline & & 94 & Newport Bay \\
\hline & SOUTH ATLANTIC & 95 & San Pedro Bay \\
\hline 36 & Albemarle/Pamlico Sounds & 96 & Alamitos Bay \\
\hline 37 & Pamlico/Pungo Rivers & 97 & Anaheim Bay \\
\hline 38 & Neuse River & 98 & Santa Monica Bay \\
\hline 39 & Bogue Sound & 99 & Morro Bay \\
\hline 40 & New River & 100 & Monterey Bay \\
\hline 41 & Cape Fear River & 101 & Elkhorn Slough \\
\hline 42 & Winyah Bay & 102 & San Francisco Bay \\
\hline 43 & N. Santee/S. Santee Rivers & 103 & Central San Francisco Bay \\
\hline 44 & Charleston Harbor & 104 & San Pablo/Suisun Bays \\
\hline 45 & St. Helena Sound & 105 & Drakes Estero \\
\hline 46 & Broad River & 106 & Tomales Bay \\
\hline 47 & Savannah River & 107 & Eel River \\
\hline 48 & Ossabaw Sound & 108 & Humboldt Bay \\
\hline 49 & St. Catherines/Sapelo Sounds & 109 & Klamath River \\
\hline 50 & Altamaha River & 110 & Rogue River \\
\hline 51 & St. Andrews/St. Simons & 111 & Coos Bay \\
\hline & Sounds & 112 & Umpqua River \\
\hline 52 & St. Marys River/Cumberland & 113 & Siuslaw River \\
\hline & Sound & 114 & Alsea River \\
\hline 53 & St. Johns River & 115 & Yaquina Bay \\
\hline 54 & Indian River & 116 & Siletz Bay \\
\hline 55 & Biscayne Bay & 117 & Netarts Bay \\
\hline & & 118 & Tillamook Bay \\
\hline & GULF OF MEXICO & 119 & Nehalem River \\
\hline 56 & Florida Bay & 120 & Columbia River \\
\hline 57 & South Ten Thousand Islands & 121 & Willapa Bay \\
\hline 58 & North Ten Thousand Islands & 122 & Grays Harbor \\
\hline 59 & Rookery Bay & 123 & Puget Sound \\
\hline 60 & Charlotte Harbor & 124 & Hood Canal \\
\hline & & 125 & Skagit Bay \\
\hline
\end{tabular}

